\title{
MADRASA BY ANY OTHER NAME Pondok, Pesantren, and Islamic Schools in Indonesia and Larger Southeast Asian Region
}

\author{
Ronald Lukens-Bull \\ The University of North Florida, USA
}

\begin{abstract}
After more than a decade studying the Indonesian pesantren, the author had an opportunity to visit similar institutions in Thailand. After placing them in historical context, this paper explores how these institutions vary in Southeast Asia. Although it is reasonable to presume that pondok between different countries and areas in the region started out virtually indistinguishable in form and function, local and national histories have shaped them differently. This paper explicitly compares pondok in three distinct areas: Indonesia, Nakhon Sri Thammarat, and the Deep South in Thailand; the former two based on fieldwork and the latter based on literature review. It is common for some analysts and governments to associate pondok with violence. The evidence suggests that this is misplaced. The paper concludes that before an authoritative statement can be made on this point, more research is needed.
\end{abstract}

Keywords: Madrasa, Islamic school, pondok, pesantren.

\section{Introduction}

Throughout the Islamic world, there are traditional educational institutions which, at a minimum, teach religious subjects including Quranic memorization, Quranic interpretation, the traditions of the Prophet (Hadi and Islamic jurisprudence (fiqb). In many parts of the world, these schools are called madrasa, although the term in Modern Arabic can refer to any kind of school. In Southeast Asia they are called variously, pondok, pondok, pesantren and pesantren.

Since the September 11, $2001 \mathrm{Al}$ Qaeda terrorist attacks in New York and Washington, Western scholars and the Western media have 
developed an interest in Islam in general, and in traditional Islamic education in particular. Nowhere is this more true than in southern Thailand. Scholarly interest in the pondok has increased as has the Thai government's concerns about pondok as hotbeds of radicalism. Although Bangkok's restrictive policies towards pondok may contribute towards the unrest, it would be unfair to characterize pondok as a key factor in the insurgency movement. Elsewhere in the region, only a handful of pondok have been linked directly to violence.

The methods used in this paper are simple. First, the Indonesian case material is condensed from prior research ${ }^{1}$. Second, the paper reviews the literature on pondok education in Thailand, which is exclusively focused on the southern border provinces (sometimes referred to as the "Deep South") and most frequently on Pattani. Third, brief visits and several hours of interviews at two pondok in Nakhon Sri Thammarat, a province in upper southern Thailand, are the basis of the third set of case material.

Typically, pondok center around a charismatic headmaster and are residential in nature. Physically, they can be virtually indistinguishable (see Figure 1). Here, I will use the term pondok to refer to all Southeast Asian madrasa-type schools because in certain places in the region the term "madrasah" means a completely different kind of educational institution. ${ }^{2}$ Further, using the term "pondok" is justified because in all three contexts, local usage would recognize the term as appropriate, if not the most common term. In Indonesia, the terms pondok and pesantren are often used interchangeably. In fact to say that one attends or attended a pesantren one uses the verb form of pondok (mondok). When speaking specifically about Indonesian pondok, I will use the more commonly used term, pesantren to be clear that the material applies best to this case and needs further study before applying it to the other cases. Further, it is not desirable to use an English gloss because no English term accurately covers the meaning of pondok.

\footnotetext{
${ }^{1}$ Ronald A. Lukens-Bull, A Peaceful Jihad: Negotiating Identity and Modernity in Muslim Java (New York: Palgrave McMillan, 2005); Ronald A. Lukens-Bull, "Two Sides of the Same Coin: Modernity and Tradition in Indonesian Islamic Education," Anthropology and Education Quarterly 32, 3 (2001): pp. 350-372; Ronald A. Lukens-Bull, "Teaching Morality: Javanese Islamic Education in a Globalizing Era," Journal of Arabic and Islamic Studies 3 (2000): pp. 26-48.

2 It is unfortunate to make a distinction in meaning based on a one letter difference in spelling, but following Indonesian usage we are left with little choice.
} 
Islamic boarding school comes the closest, but boarding school carries some meanings that might apply and there are dimensions of pondok that might be better covered by the terms seminary or even monastery, although neither of these are appropriate by themselves.

Figure 1: This pondok could be anywhere in Muslim South East Asia but is in Nakhon Sri Thammarat

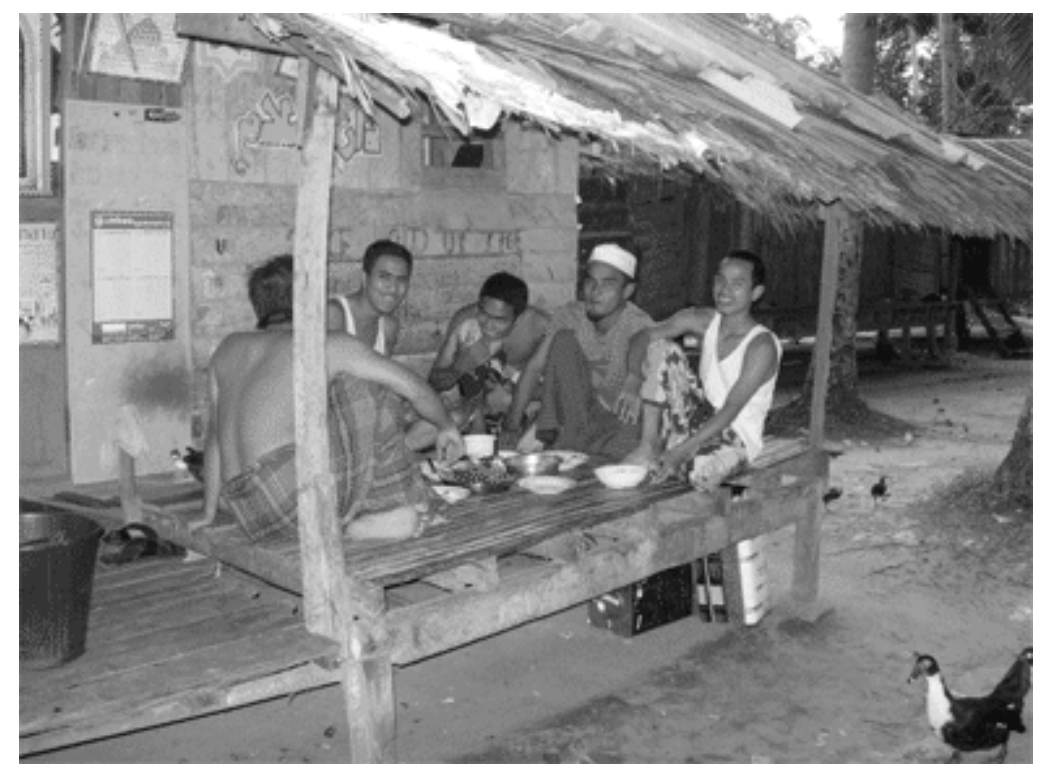

Although it is reasonable to presume that pondok between countries and areas in the region started out virtually indistinguishable in form and function, local and national histories have shaped them differently. Of particular interest are the curriculum debates and changes that arise. This paper will start with an examination of how the development policies of the Soeharto regime and globalization shaped pondok in Indonesia so that many now offer both secular education and traditional religious education. Depending on a number of local factors, they may emphasis one over the other.

In Pattani and elsewhere in the Deep South of Thailand, religious leaders have had to make a choice. Either they can maintain their identity as pondok or they can become "Islamic schools" and offer a government recognized curriculum. This can be explained in part by the turbulent political climate; that is, these government policies have been attempts to neuter the perceived threat seen in the pondok. By 
contrast, in the upper south of Thailand, at least some pondok have been able to develop and run parallel instruction in traditional religious education and in the Thai national curriculum. In this respect, they look very much like Indonesian pondok.

\section{Historical Overview of Islamic Education}

Historically speaking according to Azra, there were highly active networks of Islamic scholarship in Southeast Asia involving Muslim scholars of the Southeast Asia region in which pondok was the center of study for to learning Islamic knowledge, especially fiqh, hddita and sufism. ${ }^{3}$ In both Indonesia and Thailand, a common claim is that pondok represent a style of education unique in the Islamic world. In Indonesia, it is not uncommon for some to claim that the Indonesian pondok are unique because they combine intellectualism and mysticism. In a 1995 public lecture, Abdurrahman Wahid made such a claim by comparing Indonesian pondok to Malaysian pondok and argued that the inability of the Malaysian to combine these two dimensions lead to their disappearance. ${ }^{4}$ Because of the composition of the Javanese pondok pesantren, Zamaksyari Dhofier argues that Islam in Java did not bifurcate the Islamic sciences and so did not have two types of Islamic teachers: scholars ('ulama) $>$ and mystics (Sufis). Hence the Javanese use the unique title kyai to "indicate a Muslim scholar who is both a master in Islamic theology and jurisprudence and a Sufi master". ${ }^{5}$

The claim to uniqueness is clearly an overstatement at best, because pondok strongly resemble madrasa elsewhere in the Islamic world and both pondok and madrasa show clear continuities with

${ }^{3}$ Azyumardi Azra, The Origin of Islamic Reformism in Southeast Asia: Networks of MalayIndonesian and Middle Eastern Ulama in the Seventeenth and Eighteenth Centuries, (NSW: Allen and Unwin, 2004) p. 123

4 Preliminary conversations in Malaysia suggests that Gus Dur may be mistaken. Although pondok in Malaysia are limited to Kedah and Kelanten, there are said to teach both tassawuf as well as fiqh. See Lukens-Bull, A Peaceful Jihad: Negotiating, p.51

5 Zamakhsyari Dhofier, "The Pesantren Tradition: A Study of the Role of the Kyai in the Maintenance of the Traditional Ideology of Islam in Java" (Unpublished PhD Thesis, The Australian National University, 1980). 
educational practices in early Islam. ${ }^{6}$ The late nineteenth and early twentieth century Indonesian pesantren was an institution of advanced theological study that concentrated on fiqh (Islamic jurisprudence), ${ }^{7}$ a focus that has its roots in the medieval origins of the madrasa. In medieval Islam, learning took place in mosques in hllaqah (learning circles). Students could attend any hllaqah which interested them. ${ }^{8}$ Over time this form of education evolved into the madrasa, ${ }^{9}$ which was first and foremost committed to the study of law and therefore became the "institution of learning par excellence". The other Islamic sciences were studied as ancillaries ${ }^{10}$.

The combination of intellectualism and mysticism is by no means unique in Islam, at least in classical Islam. Pederson argues that because learning and manifestation of piety are inseparable in Islam, the madrasa (place of Islamic learning) and the ribat place of Islamic mysticism) are frequently combined. ${ }^{11}$ Makdisi argues that such combined institutions were common by the twelfth century CE, ${ }^{12}$ well before the first pesantren was established in Java. Therefore, it is incumbent on us to interrogate whether the claim of the unique twin nature of Indonesian pondok is true. If indeed, they are unique today, then we must understand what changes have taken place elsewhere in the region.

${ }^{6}$ George Makdisi, The Rise of Colleges: Institutions of Learning in Islam and the West (Edinburgh: Edinburgh University Press, 1981); Lukens-Bull, A Peaceful Jihad: Negotiating, p. 50 .

${ }^{7}$ R.A. Kern, "Pasantren" in H.A.R. Gibb and J.H. Kramers (eds), Shorter Encyclopedia of Islam (Leiden, Netherlands: EJ Brill, 1953), p. 461.

8 The only exception to this was figh halqa which were limited to members of the madhhab whose law was being taught. However, students could study a variety of fiqh halqa by freely switching their madhbab at any time, see Makdisi, The Rise of Colleges: Institutions of Learning, pp. 18-19.

9 In Arabic, the term "madrasa" means school and can apply to any kind of school including state run secular universities.

${ }^{10}$ Makdisi, The Rise of Colleges, p. 9

11 J. Pederson, "Masdjid" and "Madrasa" in H.A.R. Gibb and J.H. Kramers (eds), Shorter Encyclopedia of Islam (Leiden, Netherlands: EJ Brill, 1953), p. 351, and pp. 300310.

12 Makdisi, The Rise of Colleges, p. 10. 
I conducted my original ethnographic fieldwork in 1994-1995 and have made repeat return visits. ${ }^{13}$ Based on that fieldwork, I have published both books and articles. ${ }^{14}$ My research on this community was ethnographic which means that I lived in and around pesantren and as much as possible, lived like they lived: I ate the simple meals, kept the standards of attire and modesty, adopted the body postures which showed deference to a teacher, engaged in late night gossip and participated in ritual life. ${ }^{15}$ Unlike most anthropological research, my study took a regional rather than a village-based approach. As Bowen has suggested, the texts and rituals of Islam take the believer, and should take the ethnographer, outside the village to a "worldwide confessional community". ${ }^{16}$ A regional study allows us to explain processes beyond the boundaries of a single village. However, this is still a limited view and does not encompass the whole Islamic world. While such are the limitations of any fieldwork, the processes I examined are part of larger processes in Indonesia and the Islamic world in general. It is here that I finally turn to trying to understand pondok education in a wider perspective.

\section{Pondok Pesantren in East Java}

The Indonesian pondok, also called pesantren, ${ }^{17}$ are nearly as old as "Indonesian" Islam because of their ties to the Wali Songo (the nine saints who brought Islam to Java), ${ }^{18}$ and who all established their own

\footnotetext{
${ }^{13} \mathrm{I}$ am an anthropologist by both training and practice. An astute reader will no doubt see the disciplinary influence through this piece.

14 See Lukens-Bull, "Teaching Morality"; Idem, "Two Sides of the Same Coin: Modernity and Tradition"; and Idem, A Peaceful Jihad: Negotiating Identity.

15 Ronald A. Lukens-Bull, "Lost in a Sea of Subjectivity: The Subject Position of the Researcher in the Anthropology of Islam," Contemporary Islam: Dynamics of Muslim Life. 1, 2 (2007): pp. 173-192.

${ }^{16}$ John R. Bowen, "Discursive Monotheisms," American Ethnologist 20, 1 (1993), p. 185

${ }^{17}$ In this section, I will use the specifically Indonesian term, pesantren, to make it clear that the description here applied to the Indonesian case and requires further investigation before applying it to Thailand or Malaysia.

18 Although the Wali Songo all worked on the island of Java, they worked with various ethnic groups, so it is not appropriate to refer to Javanese pesantren or Javanese Islam in reference to them. On the other hand, used the term Indonesian to describe them projects modern nations sates back into a past in which they did not yet exist. Hence, I place Indonesian in quotation marks.
}

6 \begin{tabular}{l|l} 
JOURNAL OF INDONESIAN ISLAM \\
VOLUME O4, NUMBER O 1, JUNE 2010
\end{tabular} 
pesantren. ${ }^{19}$ A defining feature of Wali Songo's missionary activities in Java was their willingness to make accommodations with local culture. ${ }^{20}$ Specifically, they were known for their use of wayang (shadow puppet theatre) and gamelan (percussion orchestra) as well integrating the slit gong and the beduk (large drum) into the call for prayer. The purported logic was that by using sounds that people already associated with large gatherings, people would be more interested in attending the prayers. ${ }^{21}$

Another set of historical claims about pesantren further defines the identity of the pesantren community as quintessentially Indonesian. These claims concern the role of pesantren people, especially kyai in colonial resistance, the Indonesian War for Independence, and in postIndependence politics. Many nineteenth century rebellions were led by kyai. ${ }^{22}$ Kyai and their santri were very much involved in Indonesia's struggle for independence. In the written and oral histories of many pesantren is an accounting of the role played by its personnel during the war. For example, Hasyim Asyari of Tebu Ireng is said to have rejuvenated the independence effort by declaring that the war against the Dutch was jibad and required (wajib) for every Muslim within an eighty kilometer radius of the enemy. Other kyai lead their santri as guerrilla cells. This nearly universal claim of having some role in the war effort is a claim of identity; namely, that the pesantren community fought hard to be Indonesian. ${ }^{23}$

This part of pesantren history establishes that under the right circumstances, violence may be used. However, in interviews, sermons and other forums several kyai, especially those from in the Nahdlatul Ulama (NU) leadership have repeatedly made it clear that the

\footnotetext{
${ }^{19}$ IAIN (Institut Agama Islam Negeri) Sunan Ampel Research Team, Sistem Pendidikan Pesantren Kecil and Pengarubnya Terbadap Perkembangan Kepribadian Anak (Surabaya: Pusat Penelitian, 1992); Mahmud Yunus, Sejarah Pendidikan Islam in Indonesia (Jakarta: Mutiara, 1979).

20 Arguably, this assertion is only true for the majority of Wali Songo since Sunan Muria, a member of that nine saints, is reported to adhere strict ortodhoxy and show resentment toward syncretism practiced by his saints colleagues. See for instance Theodore G. Pigeud and H.J de Graaf, Islamic States in Java 1500-1700, VKI 70, 1976

${ }^{21}$ Lukens-Bull, A Peaceful Jihad, pp. 48-49.

22 Sartono Kartodirdjo, The Peasants' Revolt of Banten in 1888 (The Hague: Martinus Nijhoff, 1966).

${ }^{23}$ Lukens-Bull, A Peaceful Jihad, p. 27
} 
circumstances today are incomparable to the War for Independence. With the emergence of radical groups in Indonesia and their association with two pesantren, NU leadership seeks to distance itself from radical Islam. Part of their strategy is to restrict the definition of pesantren so as to exclude those associated with violence.

While a few pesantren have been directly associated with violence (specifically those associated with Abu Bakar Baasyir and Ja'far Umar Thalib), there is no evidence to suggest that there is a widespread problem other than reading Taliban-esque madrasas into the Indonesian context.

In Indonesia, stories about the involvement of pesantren in violence (in the name of Independence) are outnumbered by stories about the Wali Songo, who are known for making accommodations with local culture. Specifically, they are known for their use of wayang. One way this was done was by reinterpreting the Hindu epics in Islamic ways. ${ }^{24}$ While all the Wali Songo established pesantren, none of the Wali Songo pesantren have survived to the present day. It is almost cliché in Indonesia to say that all pesantren are their descendents and all kyai are seen as inheritors of the role of the Wali Songo.

Because kyai are considered to have inherited the role of these saints, most kyai adopt the style and methods of the $W$ ali Songo. This means meeting people where they are. Rather than preaching against popular practices, they accept that people want to do these things and strive to teach them a more orthodox way of conducting and understanding these rituals. This history also means that Indonesian Islam has strong pietistic elements, meaning that doing right is left to the individual's conscience. The pace of preachers and teachers is to heighten awareness (keyakinan) so that people will be inspired to live as good Muslims. Frequently quoted passage of the Quranic is an injunction that there should "be no compulsion in religion". ${ }^{25}$

\footnotetext{
${ }^{24}$ For example, in the Mahabarata, Arjuna has a secret weapon called the Kalimasada, which Javanese Muslims say is short for Kalimah Shabada, or the Islamic Confession of Faith. Some have argued that the highly stylized human forms in the Javanese wayang puppets reflect the influence of Islam which discourages the artistic representation of the human form.

${ }^{25}$ Qur'aæ, 2:256. Although this passage is multi interpretable, moderate Muslims use this passage along with similar passage to argue against formalization of shari $x h$ in religiously pluralistic Indonesia.
} 
Therefore the establishment of Shari $2 h$ as a national law enforced by the state has long been rejected by most Indonesian Muslims.

\section{Curriculum}

The curriculum found in contemporary pesantren can be divided into four basic areas: religious education (J.: ngaji), character development (I.: pengalaman; literally, experience), vocational skills training (I.: ketrampilan) and general education (I.: sekolab). The first three types of instruction are rigidly gender segregated. At some pesantren, general education may be co-educational following the example of the government schools, though this has proven to be somewhat problematic. Religious education involves studying texts, which include the Qur'an, Hadith and the classical texts which include commentaries on scripture, expositions on mysticism (A.: tas dwwnf, thriqab), morality (A.: akblapt, pedagogy as well as texts on jurisprudence (A.: fiqh), doctrine (A.: aqi ash, us $>$ ad-di $\rightarrow$, Arabic grammar (A.: nabuy, sgrof, balagha) and prayers and invocations (A.: du $a_{3}>$ wirid, mujarrabat). ${ }^{26}$

An additional, even central, component of pesantren religious education is Islamic mysticism or Sufism. Key texts are studied and mystical practices, such as dhikir (A.: chanting religious formulae; literally, remembrance of God) are integrated into daily activities. Sufism as practiced in pesantren insists on a mysticism subject to normative Islam and distinguishes between intellectual, emotional and organizational components of Sufism. ${ }^{27}$ Related practices are special intercessory prayers called istigho repetitive chants, communal meals to invoke blessing and grave visitation.

In addition to religious education and character development, many pesantren have curricula designed to teach their students the skills and knowledge to find employment after they graduate. General education usually includes one of two basic government recognized curricula, one mostly secular and the other with a greater emphasis on religious training. Pesantren may have neither, either or both types of

${ }^{26}$ Martin van Bruinessen, "Kitab Kuning: Books in Arabic Script Used in the Pesantren Milieu," Bijdragen 146, 2/3 (1990), p. 229.

27 Zamakhsyari Dhofier, The Pesantren Tradition: A Study of the Role of the Kyai in the Maintenance of the Traditional Ideology of Islam in Java (Tempe: Program for Southeast Asian Studies, 1999). 
schools within their grounds. Skills training includes welding, automotive mechanics, carpentry, sewing, computers, shop keeping and other vocational skills. How exactly pesantren at this level accommodate these areas in their curriculum is part of how they negotiate modernization and globalization ${ }^{28}$

In Indonesian discourse, how a pesantren engages these areas leads to one of three labels: salaf (A.: traditional), khalaf (A.: modern) and terpadu (I.: mixed). By 2007, a new category-salafi pondok-had emerged. Although, this is a distinction marked by a single letter (salaf/salafi), it is a meaningful distinction for Indonesians. Salafi pondok, of which there are an estimated thirty or so, follow salafi/wahabi teachings. ${ }^{29}$

Salaf pesantren have only religious education and character development. Salaf pesantren best preserve the teaching of classical texts as essential education. They still observe maz̧hab (Islamic school of law) and therefore taqlid (adherence to classic authority) In Indonesian case Shafi ie is the mazhab of traditional Muslims. Khalaf pesantren are characterized by religious education conducted exclusively in Indonesian, and by the importance placed on general education and skills training. The less an institution emphasizes religious education and character development, the less likely it is to be considered a true pesantren. The most traditional pesantren tend to limit the innovations used in the teaching of this curriculum. Salaf pesantren are known for the best religious education, or at least the most traditional, and modern pesantren are best known for their capacity to teach Arabic and English. The most well-known modern pesantren, Darussalam of Gontor, also promotes ijtihad (independent interpretation) as opposed to taqlid of salaf pesantren. However, some argue that salaf graduates are not as well prepared to deal with broader social issues facing a changing society. Therefore they are not as readily accepted by the masses as graduates of modern pesantren. However, this assertion is contested and cannot be accepted at face value. Most pesantren today are labelled mixed because they engage some combination of all four types of curriculum. Even so, there is considerable variation within this category.

The typology given above is far from static, even if it reduces a dynamic process to a static model. Indonesians, both from within and

\footnotetext{
${ }^{28}$ Lukens-Bull, A Peaceful Jihad.

29 Abdurrahman Ma'sud, Personal Communciation, August 2007.
} 
without the pesantren community, have created these typologies as a way of getting a handle on the changes taking places. However, the fact that a majority of pesantren could be placed in the terpadu category speaks to the extent of the changes taking place. There is a great deal of variation within this terpadu category. The very term for the middle category, terpadu or mixed, suggests strongly that changes are taking place. The fact that most pesantren would classify themselves as terpadu, means that it is highly desirable to be seen as a school that is balancing traditional religious education and modern educational needs.

Since it is the headmasters, rather than the functionaries at a place of worship, who lead the Indonesian Islamic community, maintaining pesantren as viable schools is critical to maintain classical Islam in Java. Without large numbers of students who will have life-long allegiances to a kyai, the headmaster's ability to influence society is greatly reduced. Therefore, some of these curricular changes have to do with maintaining influence over society. ${ }^{30}$

In this context, it may seem that salaf pesantren are reactionary and reject accommodation with modernity - and at some level this may be so. However, several salaf pesantren, I visited encourage students to complete the government required minimum nine years of recognized education prior to beginning studies at the pesantren. Further, several Ulama $>$ families have adopted the strategy of a double education for their children (primarily sons) in which they complete government recognized education through the college level and then seek a more traditional pesantren education at a salaf pesantren. In this way salaf pesantren become part of the overall strategy of the pesantren community to maintain tradition while adapting to modernity. ${ }^{31}$ Because of this attitude to modernity, it is very unlikely that salaf pesantren would show inclination toward radicalism and violence.

Having sketched the Indonesian pesantren based on decades of research, the paper now turns to similar institutions in Thailand. After reviewing the literature about pondok in the southern border provinces, the paper then turns to ethnographic data from the upper south.

\footnotetext{
${ }^{30}$ Lukens-Bull, A Peaceful Jihad, p. 69

31 Ibid.
} 


\section{Pondok in Pattani}

The most complete and significant work on the Thai pondok is Hasan Madmarn's The Pondok and the Madrasah in Patani. Madmarn divides the typical day at traditional pondok into three sessions. The morning session starts upon the heels of the dawn prayer. During this minimally two hour session, the teacher reads from two kitab. ${ }^{32}$ After this direct teaching, students take their breakfast. During the rest of the morning, beginners will study kitab from one of the headmaster's (tok guru) assistants. After noon prayers, the second session begins and lasts until the afternoon prayers. The final session starts after sunset prayers and continues until the evening prayers. Madmarn does not make any distinction in the method or content between the three sessions. After evening prayers, some students will be found trying to memorize the day's lessons. ${ }^{33}$

Madmarn makes a distinction between the pondok learning system and the madrasab learning system. For Madmarn, pondok learning is typified by a circle of students around a teacher being taught directly. Pondok learning does not involve blackboards, desks or any of the other accoutrements of classroom education. There are no grades in either sense of the word; no exams or steps through which to progress. Madmarn defines madrasab learning only by stating that it is not the same as the pondok system and is what is typically found in Muslim countries. ${ }^{34} \mathrm{He}$ speaks to a distinction also made in Indonesia, where madrasab has come to mean a religious school, typically a day school, that uses a "modern" classroom (desk, chairs and blackboards) and school structure (graduated classes or grades). Despite these localized understandings of madrasah, pondok (or pesantren) still belong to this pan-Islamic concept of madrasa, ${ }^{35}$ something Madmarn himself recognizes. ${ }^{36}$

As Madmarn's argument unfolds, it becomes clear that the madrasah learning system is the way in which the Muslim community in

\footnotetext{
32 Hasan Madmarn, The Pondok and the Madrasah in Patani (Bangi: Penerbit Universiti Kebangsaan Malaysia, 2002), p. 62.

33 Ibid., pp. 62-66

34 Ibid., p. 21.

${ }^{35}$ Unfortunately, this is a another case of a distinction of meaning marked by a single letter.

${ }^{36}$ Madmarn, The Pondok and the Madrasah, p. 55.
} 
Thailand is facing the challenges of government curricular involvement. With the 1982, Act 15 (2) law, the Thai government intensified the process of trying to bring Islamic education under its control. Specifically the Ministry of Education enacted three strategies. The first was to encourage all pondoks to become officially registered and hence legally recognized. This implies that all unregistered pondok became illegal. Secondly, registered pondok were encouraged to begin the transformation into Islamic private schools. The third strategy was to ban the establishment of any new pondoks. ${ }^{37}$ In 1987, the number of years of compulsory education was raised from six to nine, with the hope that more time in school would mean a greater command and use of Thai as well as more general knowledge and competencies. 38 Indeed, the Muslims in southern Thailand feared that this was all part of a government strategy to assimilate them and to eventually have them no longer be Muslims. ${ }^{39}$ It would be an overstatement to attribute the recent violence solely to these sentiments towards government policies, but it reasonable to include them as contributing factors to the resentment towards Bangkok-driven policies.

The emergence of the madrasah system with its testing, grading and diplomas allows Thai Muslim students to study in Middle Eastern universities like al-Azhar; something they could not do with the traditional pondok learning alone because of the need for accreditation and documentation. ${ }^{40}$

What is clear from Madmarn and other literature on the South, as well as conversations with other researchers working in the area including both Chris Joll and Che Husna at Universiti Kebangsaan Malaysia, there are two types of Islamic schools in the Deep South. The first is the pondok which may use the traditional pondok learning system or the madrasab learning system. And the second is the Islamic school that instructs according to the Thai government curriculum. It seems that in the Deep South at least, there is no room for hybrid systems of education. But a hybrid institution, of the kind all too common in Java, can be found in Nakhon Sri Thammarat (NST).

\footnotetext{
${ }^{37}$ Ibid., p. 72.

38 Ibid., p. 75.

39 Ibid., p. 76.

40 Ibid., p. 81.
} 


\section{Pondok in Upper Southern Thailand ${ }^{41}$}

Two pondok were visited in NST. The first was a simple affair and moderately sized. It was not involved in government curriculum and was what in Java would be called a salaf pondok. This is consistent with the literature: to be involved with the government general curriculum meant giving up traditional pondok education. However, the other pondok visited challenges the literature on this point.

Pondok Ban Tan, frequently referred to as "Dr. Surin's Pondok" because of its association with Surin Pitsuan (MP, former Thai Foreign Minister and now Secretary-general of the Association of Southeast Asian Nations), manages to engage both the kingdom's curriculum and traditional pondok education. Surin has little to do with the day to day function of Pondok Ban Tan but is considered by the pondok staff to be the pondok's benefactor and sponsor. Surin's mother is the headmistress of the school. The primary respondent was another one of her sons: however, typical of research in the region, a small crowd gathered and the conversation included several teachers and family members.

The school was founded 64 years ago by Surin's great-grandfather and is currently run by his mother, who is referred to by all in the pondok as "Mama". There are about 1,300 student attending and living at Pondok Ban Tan of which there are about an even number of boys and girls. In the late 1960s and the early 1970s, Pondok Ban Tan added government recognized curriculum. This is striking because at the same time in Indonesia, the adoption of secular education in pesantren became widespread. My own research showed that this change was motivated in part by parental desires for their children to have both solid religious knowledge and values and an education that suited them for the emerging modern marketplace. Hefner observes that this desire for a dual purpose education is found throughout the contemporary Islamic world. ${ }^{42}$ It is reasonable to presume that Pondok Ban Tan was responding to similar demands.

The staff said that most Muslim parents want their students to study in pondok because they do not have much knowledge about Islam

\footnotetext{
41 The research discussed in this section was enabled by a Fulbright Senior Specialist Grant which placed the author at Walailaik University in NST.

42 Robert Hefner and Muhammad Qasim Zaman (eds), Schooling Islam: Modern Muslim Education (Princeton: Princeton University Press, 2006).
} 
and do not want their children to be like them in that regard. Cost is another inducement because pondok are relatively inexpensive: $200 \mathrm{baht}$ (approximately US\$ 6) per semester for the general curriculum school, but no tuition for kitab education.

\section{Local and National Contexts}

Unlike Bangkok, in which explicit expressions of Islamic identity such as mosques, Muslim food stalls and women wearing hifal (head covering) get swallowed up in a sea of Buddhism, state cults, and global capitalism with all its trimmings, the Muslim community is a real presence in NST. On Fridays, men adorned in the best prayer clothes head to the mosque. Women regularly wear hifalsand every major food court has at least one Muslim food stall. Also, unlike Pattani, the community is not strongly associated with a Malay identity; many Muslims here speak Thai exclusively. NST was once the home of a major Islamic kingdom and is also seen as the entrée point for Buddhism into Thailand. Today, about 10 per cent of the community is Muslim.

As Muslims in a Buddhist country, they face certain issues and concerns. ${ }^{43}$ One clear concern has to do with male-female interactions. Complete gender segregation in the school is considered impractical because it fails to prepare students for the realities of the society in which they live. Therefore, the school is co-ed. During the national curriculum classes, boys and girls sit in different sections/sides of the class room. As I observed the religious lesson (part of the national curriculum) that was being held in the musholla had them on opposite sides but did not have a barrier between them. On the other hand, during kitab lessons a curtain is erected between the boys and the girls. Unlike Indonesian pondok, there was no wall between the dwellings for boys and girls but simply a space or a sort of "no man's land". The staff commented that they create a wall in the students' hearts.

The reason the pondok does not rigidly separate them is that keeping them completely separate does not match up with the realities of society. The teachers who spoke with the author suggested that in

\footnotetext{
${ }^{43}$ Unlike in Indonesia where Islam exists in virtually all regions, Islam in Thailand only inhabits its southern region of Thailand known as Pattani, whereas the majority of Thai people are Buddhist. Pattani Muslims were incorporated into Thailand by force in the eighteenth Century. ${ }^{43}$ See for example Azra, The Origin of Islamic Reformism in Southeast Asia, p. 122.
} 
Thailand, as a Muslim minority, it is not possible to create the kind of gender segregated society found in Saudi Arabia. When the students leave school they will have to interact with the opposite sex. Therefore, the pondok must teach students them how to conduct themselves. I heard similar arguments at Tebu Ireng, the most famous of Javanese pondok, to justify having coed education in their "secular" school. However, most other pondok in Java reject this kind of argument.

Another issue concerns sociability and participation in community events. During a university hosted Loi Krathong festival, student organizations ran carnival booths as fund raisers for their respective activities budgets. This Thai festival is considered by most to be a cultural event rather than a specially religious Buddhist event. However, the key ritual, placing a float with a candle in the river, is aimed at seeking the blessings of the "Mother of the Water". What is interesting in this context is that Muslims ${ }^{44}$ also participated in this event. When asked about this, the pondok staff said that while the festival may be cultural rather than religious, it is "not our culture" and that while it is acceptable to go and watch and even partake of the festival market, it is not appropriate for Muslims to engage in the ritual itself. On the other hand, they maintain good relations with the local $W$ at and regularly help them in building and renovation projects.

In terms of curriculum, for the "school" portion of the day, they follow the Kingdom's curriculum. This is even true for the religious classes within the curriculum. However, since the vast majority of the students live in the pondok, they can use the mornings and evenings to supplement the government curriculum. When presented with the fact that during the Soeharto era pesantren in Java would "buck the system" and take various steps to offset the official view on religious matters, the staff said that because the people who write the government curriculum also follow the Syafii legal school, they have no conflict with text books. However, in their view kitab are clearly the better source for instructions. The clear preference for kitab over derivative texts was found throughout Javanese pesantren as well.

\footnotetext{
${ }^{44}$ An interesting side note is that beyond the few people that I knew individually who were Muslim, the only other identifiable as Muslim were women wearing hijab, showing how both local and scholars use it as a marker for religious identity although it is a problematic marker for two reasons. Only those wearing it are seen as Muslim and therefore a particular burden for marking "Muslimness" is placed on women.
} 
To get a general sense of educational activity at Ban Tan it is useful to review the schedule for a typical day at the school:

Figure 2: Daily Activities at Pondok Ban Tan

\begin{tabular}{ll}
\hline Time & Activity \\
\hline 05:30 am & Morning prayers \\
06:00 am - 06:30 am & Quranic lessons \\
07:20 am & National flag ceremony - The staff maintained that \\
& it was basically the same as one would see at a \\
& government or Buddhist school but with the simple \\
& substitution of Islamic prayers before the flag \\
& ceremony \\
& A short homily encouraging the students according \\
& to Islamic principles. \\
07:30 am & "Mama" teaches Quran over the PA system. \\
& Religion class. This is part of the national \\
07:45 am & curriculum. \\
08:00 am - 10:30 am & Secular education - math, language, science, \\
& including Malay lessons \\
10:30 am - 04:30 pm & There is a break for midday prayers and lunch. \\
& Afternoon prayers. \\
Midday & The students may relax and prepare and eat their \\
04:30 pm & dinners. \\
04:45 pm & Maghrib prayers. \\
& Kitab lessons \\
06:30 pm & Isyak prayers \\
06:30 pm & \\
$08: 00 \mathrm{pm}$ &
\end{tabular}

It appears that between the hours of $8 \mathrm{am}$ and $4: 30 \mathrm{pm}$, that they follow the approved curriculum for Islamic schools. But in the early morning and evening, they supplement with traditional pondok education based on classic kitab. This schedule closely parallels the pattern common in terpadu pondok in Java. Furthermore, students who have completed the government course of education, turn to full time study of the classical kitab. Approximately five per cent of the students stay on after graduation to study kitab in preparation to become religious scholars and religious leaders (Tok Alim and Tok Imam). In this regard, Pondok Ban Tan is like many Javanese pondok who have added secular education; a select number of students stay on after graduation to complete the traditional pondok training. 


\section{Kitab Study}

The kitab used at Ban Tan can be divided into those that are exclusively Jawi (Malay in Arabic script) and those that are Arabic with Jawi interlinear. The first type are called by Madmarn "Kitab Jawi", ${ }^{4}$ and may have been written by the ulama of Pattani, although none of the titles given could be correlated with the major titles identified by Madmarn. ${ }^{46}$ Since most of the students are not really conversant in Malay, after the Jawi is given, an explanation will be given in Thai. A parallel is found in Java, where the interlinear is in Arabic-scripted Javanese and today many students come from outside Java and do not speak Javanese. So, in both places, the lesson may well be trilingual: Arabic, Javanese or Jawi, and Indonesian or Thai.

There was a great deal of emphasis on the importance of kitab and the fact that they are what makes them Muslim. The staff made it plain that the pondok system, using the kitab, instills faith (Iman) very deeply and that the kitab transmits the "knowledge" better than a modern book. This emphasis on kitab is directly parallel with the Javanese pesantren. As one Ban Tan staffer put it "Kitab is way of life for Muslim people".

Figure 3: Kitab Instruction at Pondok Ban Tan

\begin{tabular}{lll}
\hline Kitab & Subject & Language \\
\hline Sabilillah & Fiqh & Jawi \\
Idul Hunbah & $\begin{array}{l}\text { Marriage laws and the relationship } \\
\text { between husbands and wives }\end{array}$ & Jawi \\
Bayut Tun & Fiqh and Tauhid & Jawi \\
Mutal 'ain & Fiqh & Jawi \\
Panawar & Ahlaq & Jawi \\
Yahul Marhuba & Basic Syaffi Tassawuf with no & Jawi \\
& specific tariqoh & \\
Tafsir Jaelilin & Quranic Interpretation & Arabic/Jawi \\
Tafsir Nur & Quranic Interpretation & Arabic/Jawi \\
Yahsin & & \\
Riyadus Sholihin & Hadith (Bukari and Muslim) & Arabic/Jawi \\
Pahwaki & Nahwu Shorof (Arabic grammar) & Arabic/Jawi \\
\hline
\end{tabular}

Advanced students may teach the younger students as is traditional in the pondok system elsewhere, but there is considerable pressure of

\footnotetext{
${ }^{45}$ Madmarn, The Pondok and the Madrasah, p.17.

46 Ibid., pp. 23-32
} 
the part of the government to change this. The advanced students who want to become religious leaders will spend another two years studying kitab here. Following that, most study for another three or so years in the southernmost provinces. Others go to Al-Azhar in Cairo, Medina, Malaysia and even to Indonesia.

Because of the unrest in the south, the Thai government has stepped up efforts to register all pondok schools and put them under government regulation. One outcome of the increased involvement of the government in education can be seen in the striking linguistic shifts that have taken place in NST. Ban Tan staffers suggested that all Muslims from NST were originally from Kedah, Kelantan, or Perlis in Malaysia or from Pattani. In three generations there has been a linguistic shift wherein grandparents speak only Malay, their children speak both Malay and Thai, and their grandchildren speak only Thai. Increased involvement in the Thai education system is the leading cause for this shift. Indeed more people at the pondok were able to speak English than could speak Malay. This rapid linguistic shift is an area ripe for research for the right linguist.

\section{Conclusion: Future Research}

What should be clear from this brief discussion is the need for considerably more research explicitly examining the parallels and relationships between pondok throughout Southeast Asia. Specifically there are four fruitful fields that seem obvious. The first is to examine carefully the histories of pondok education in each national setting. Although some researches have been conducted to show direct links in the early history (i.e. before the nineteenth century) of Islam in the region, examining contemporary links will be very useful. One link will emerge from those Thai pondok students who study in either Malaysia and Indonesia. Other ties might emerge from schoolmates from around the region studying together at Al-Azhar or other Middle Eastern institutions. The second area of interest would be the content of the kitab used throughout the regions. What exactly is the relationship between the Kitab Jawi of southern Thailand and Malaysia and the Kitab Kuning of Indonesia? Third, an examination of how local and national contexts have shaped pondok differently will contribute to theoretical understandings of how local Islam's, received Islam and Universal Islam interact. Finally, it is will be useful to examine the assumption that pondok throughout the region are radicalizing. Data 
collected to date does not suggest that this is a widespread trend but this remains an important area to investiage. []

\section{Bibliography}

\section{Books and Articles}

Azra, Azyumardi, The Origin of Islamic Reformism in Southeast Asia: Networks of Malay-Indonesian and Middle Eastern Ulama in the Seventeenth and Eighteenth Centuries, (NSW: Allen and Unwin, 2004)

Bowen, John R. "Discursive Monotheisms." American Ethnologist. 20, 1 (1993).

Hefner, Robert and Muhammad Qasim Zaman (eds). Schooling Islam: Modern Muslim Education. Princeton University Press, 2006.

IAIN (Institut Agama Islam Negeri) Sunan Ampel Research Team. Sistem Pendidikan Pesantren Kecil and Pengarubnya Terbadap Perkembangan Kepribadian Anak. Surabaya: Pusat Penelitian, 1992.

Kartodirdjo, Sartono, The Peasants' Revolt of Banten in 1888. The Hague: Martinus Nijhoff, 1966.

Kern, R.A. "Pesantren." in H.A.R. Gibb and J.H. Kramers (eds). Shorter Encyclopedia of Islam. Leiden, Netherlands: EJ Brill, 1953.

Lukens-Bull, Ronald A. "Teaching Morality: Javanese Islamic Education in a Globalizing Era." Journal of Arabic and Islamic Studies. 3 (2000): pp. 26-48.

------. "Two Sides of the Same Coin: Modernity and Tradition in Indonesian Islamic Education." Anthropology and Education Quarterly. 32, No. 3 (2001): pp. 350-372.

--------. A Peaceful Jihad: Negotiating Identity and Modernity in Muslim Java. New York: Palgrave McMillian, 2005.

--------. "Lost in a Sea of Subjectivity: The Subject Position of the Researcher in the Anthropology of Islam." Contemporary Islam: Dynamics of Muslim Life. 1, 2 (2007): pp. 173-192.

Madmarn, Hasan. The Pondok and the Madrasah in Patani. Bangi: Penerbit Universiti Kebangsaan Malaysia, 2002.

Makdisi, George. The Rise of Colleges: Institutions of Learning in Islam and the West. Edinburgh: Edinburgh University Press, 1981. 
Pederson, J. "Masdjid' and 'Madrasa'." in H.A.R. Gibb and J.H. Kramers (eds). Shorter Encyclopedia of Islam. Leiden, Netherlands: EJ Brill, 1953 p. 351, 300-310.

Pigeud, Theodore G., and H.J de Graaf, Islamic States in Java 1500-1700, VKI 70, 1976

van Bruinessen, Martin. "Kitab Kuning: Books in Arabic Script Used in the Pesantren Milieu." Bijdragen. 146, $2 / 3$ (1990).

Yunus, Mahmud. Sejarah Pendidikan Islam in Indonesia (History of Islamic Education in Indonesia). Jakarta: Mutiara, 1979.

Zamakhsyari, Dhofier. "The Pesantren Tradition: A Study of the Role of the Kyai in the Maintenance of the Traditional Ideology of Islam in Java." Unpublished Ph.D Thesis, The Australian National University, Canberra, 1980. 